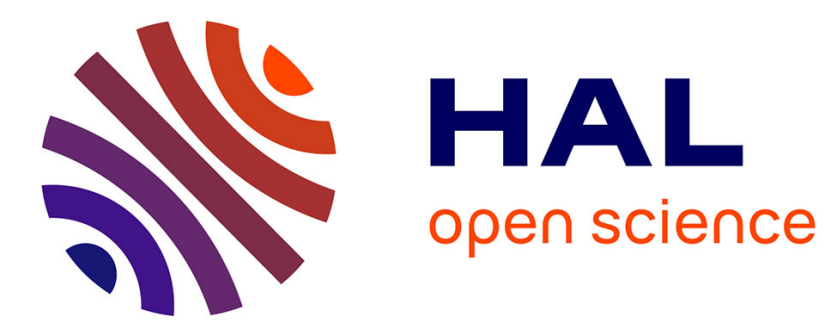

\title{
An efficient enzymatic-based process for the extraction of high-mechanical properties alfa fibres
}

\author{
Sabrine Hanana, Ahmed Elloumi, Vincent Placet, Hajer Tounsi, Hafedh \\ Belghith, Chedly Bradai
}

\section{- To cite this version:}

Sabrine Hanana, Ahmed Elloumi, Vincent Placet, Hajer Tounsi, Hafedh Belghith, et al.. An efficient enzymatic-based process for the extraction of high-mechanical properties alfa fibres. Industrial Crops and Products, 2015, 70, pp.190 - 200. hal-02963407

\section{HAL Id: hal-02963407 \\ https://hal.science/hal-02963407}

Submitted on 10 Oct 2020

HAL is a multi-disciplinary open access archive for the deposit and dissemination of scientific research documents, whether they are published or not. The documents may come from teaching and research institutions in France or abroad, or from public or private research centers.
L'archive ouverte pluridisciplinaire HAL, est destinée au dépôt et à la diffusion de documents scientifiques de niveau recherche, publiés ou non, émanant des établissements d'enseignement et de recherche français ou étrangers, des laboratoires publics ou privés. 


\title{
An efficient enzymatic-based process for the extraction of high-mechanical properties alfa fibres
}

\author{
Sabrine Hanana ${ }^{1,2,3^{*}}$, Ahmed Elloumi ${ }^{1}$, Vincent Placet $^{2}$, Hajer Tounsi ${ }^{3}$, Hafedh Belghith ${ }^{3}$, \\ Chedly Bradai ${ }^{1}$ \\ ${ }^{1}$ Electromechanical Systems Laboratory LASEM , National Engineering School of Sfax, \\ University of Sfax, Soukra km 4, 3038 Sfax, Tunisia \\ ${ }^{2}$ FEMTO Institute, Applied Mechanics Department, UMR CNRS 6174, University of Franche- \\ Comté, 24 Chemin de l'Epitaphe, 25000 Besançon, France \\ ${ }^{3}$ Laboratory of Biomass Valorisation and Proteins Production in Eukaryotes, Centre of \\ Biotechnology of Sfax, University of Sfax, Sidi Mansour, PB" 1177”, 3018 Sfax, Tunisia
}

*Corresponding author:E-mail address hnana-sabrine@hotmail.fr

Tel.: +21-6-20-77-39-19

\begin{abstract}
Alfa fibres, which are generally extracted from the leaf of a plant belonging to the Poaceae family (Stipa tenacissima L), originating from the center of Tunisia, are mainly used for pulp and paper applications. Their potential use as reinforcement in polymer composites requires the understanding of their microstructure and mechanical properties and a proper control of fibre extraction and transformation processes. This work investigates the morphology of the alfa plant (leaves and fibres) through optical and electron microscopy. The extraction process combining mechanical, chemical and enzymatic stages and the reaction time of the enzymes have been optimised to achieve the highest mechanical properties of fibres. The effect of enzymatic treatments (laccase, pectinases and xylanases) on the morphological, chemical composition and mechanical properties of alfa fibres was investigated and the effectiveness of enzymatic treatments
\end{abstract}


has been evaluated. The chemical compositions of alfa are correlated with its mechanical properties. The result indicates that the tensile properties of isolated fibres were greatly improved when an optimised enzymatic-based process is used to separate the fibres from the leaves. Using pectinase and xylanase activities, results show really high mechanical properties, with an average rigidity and strength up to respectively 66 GPa and $1300 \mathrm{MPa}$, which make alfa fibre promising reinforcements for load-bearing composite materials. This work also showed that enzymes offer an attractive and ecofriendly approach to efficiently extract high-performance plant fibres.

\section{Key words:}

Alfa fibre; fibres extraction; enzymatic treatment; xylanase, pectinase, laccase; mechanical properties.

\section{Introduction}

In Tunisia, Stipa tenacissima also known as Arab name alfa is located in the centre of the country, where it covers about $3500 \mathrm{~km}^{2}$ with an annual production of approximately 60.000 tons (Ben Brahim and Ben Cheikh, 2007). Alfa plant farming is relatively eco-friendly since it does not need insecticides and pesticides and only a small amount of water is necessary for its growth. This species plays an important role in social, economic, cultural and industrial development. The alfa leaves have long been used for crafts such as cordage and objects of sparterie (objects made out of rough fibres such as plaiting materials, basketware and wickerwork), alfa germinated seeds may be consumed by humans, the alfa leaves have unsaturated fatty acids, including oleic acid and linoleic acid (Mehdadi et al., 2000), which could be valued in the dietary domain and younger alfa leaves can be grazed by horses, camels but it is too rich in lignin for other herbivores. It also constitutes an essential factor in the pastoral balance and desertification fighting. 
With its powerful root system, it prevents land degradation and soil erosion caused by wind and water dry land region (Zeriahène $\mathbf{N}, \mathbf{1 9 8 7}$ ).

Alfa fibres extracted from the leaves are mainly used for pulp and paper applications. The Tunisian company SNCPA (National Company of Cellulose and Alfa Paper) produces about 40.000 tons of alfa pulp per year from alfa plant. $30 \%$ of this production is exported to Europe, Asia and the United States of America. The alfa fibres are generally extracted from the leaves by the sodium hydroxide process which consists in cooking the leaves in $\mathrm{NaOH}$ solution, followed by the bleaching of the obtained fibres in bi-oxide chloride solution or hydrogen peroxide solution (Bouri et al., 2010). The extraction process provides access to short, fine and white fibres and then a high quality pulp. This process also leads to a degradation of the cell wall, which is detrimental for the mechanical properties of the isolated fibres. The experimentally determined properties are in the order of magnitude of 5 to $20 \mathrm{GPa}$ and 50 to $250 \mathrm{MPa}$ respectively for the tensile rigidity and strength according to literature (Ben Brahim et al., 2007 and Dallel (2012)). Bessadok et al., (2009) show that high-mechanical properties can be reached (tensile strength greater than $1400 \mathrm{MPa}$ and Young's modulus up to $70 \mathrm{GPa}$ ) if the defibration process is optimised.

In pulp and paper application, the mechanical potential appears to be poorly exploited. An expected step for Maghreb countries is to attract industrial interests towards the use of alfa fibres in high added value applications, such for textiles and composite materials. In fact, some studies and applications have dealt with the elaboration of composites. Ben Brahim et al., (2007) have reported that mechanical properties of the alfa/polyester composites are, for the same weight, close to those measured on composite reinforced with synthetic fibres such as glass 
fibres. In the case of textile applications and for the first time, Dallel (2012) produced yarns based alfa fibres (up to $90 \%$ ) by the conventional ring spinning method. These yarns have an average tenacity of $6.5 \mathrm{CN} /$ tex and a relative elongation of $4.3 \%$. Before considering such applications, an extensive mechanical characterisation work as a function of the fibre extraction process has to be performed. Alfa fibre has been far less studied in comparison to other plant fibres and its morphology, biochemical composition, ultra structure and mechanical behaviour are far from being fully understood.

Very few researches have concerned the analysis of alfa fibre quality and, as far as we know, none of them concerned the comparison of different extraction methods and their effects on fibre mechanical properties. The well-known processing methods for flax and hemp could probably be adapted for alfa: they include water or microbiological retting plus mechanical scotching or sometimes enzymatic processing (Akin et al., 2001; Kashyap et al., 2001; Hoondal et al., 2002; Van Sumere, 1992). These controlled methods are more expensive than dew retting but usually produce better quality fibres (Bacci et al., 2010) and a better reproducibility of the fractionation level.

The use of enzyme technology is becoming increasingly substantial for the processing of natural fibres (George et al., 2014; Liu et al., 2012; Alix et al., 2012). A major reason for embracing this technology is the fact that the application of enzymes is environmentally friendly. The reactions catalyzed are also very specific and have a focused performance (Bledzki et al., 2010).

The main purpose of this work is to implement eco-friendly process based on enzymatic treatment on alfa fibres, in order to extract and separate the fibres from the leaves and to preserve their native mechanical properties. In first time, we analyse the fibres 
morphologies; using electronic and optical microscopy for the observation of the transverse and longitudinal cross-sections of alfa leafs. Then we propose, in the second time, an eco-friendly process for the fibres extraction. The effectiveness of enzymatic treatments has been evaluated using four main criteria: (i) determining the amount of solubilized sugars after enzyme incubations, (ii) by observing bleachability, (iii) observing the fibre separation level, (iv) determination of the chemical composition of the fibres extracted and (v) measuring the mechanical properties of isolated fibres Tensile tests were performed for each extraction step on isolated alfa fibres in order to determine their mechanical performances and evaluate the severity and efficiency of the process.

\section{Materials and methods}

\section{$2.1 \quad$ Plant material}

Alfa plants used in this work were collected in December 2012 in the locality of Faj El Hdid, Hassi El Farid delegation in the governorate of Kasserine. All the informations about the climate of Hassi El Farid were collected: the area is semiarid, the temperature ranges from $2^{\circ} \mathrm{C}$ to $12^{\circ} \mathrm{C}$ in winter and $30^{\circ} \mathrm{C}$ to $40^{\circ} \mathrm{C}$ in summer and the average annual rainfall is 335 millimetres.

\subsection{Fibre extraction}

The extraction of alfa fibres was carried out following different paths: mechanical, enzymatic and chemical steps in order to properly separate the elementary fibres and to better evaluate their morphological and mechanical properties as shown in figure 1. 


\subsubsection{Leaf preparation}

The first step included the removal all impurities (dead leaves, straw, dust ...) from the raw material. The average leaf's diameter was determined using measurements performed every $5 \mathrm{~cm}$ along the leaf lengths (generally comprised between 52 and 68 $\mathrm{cm})$. Figure 2 shows that the variation of the diameter from the upper and lower extremity is very important, from approximately $1.2-1.6 \mathrm{~mm}$ to $0.5 \mathrm{~mm}$ for the considered leaves. The top end of the leaf is in the form of acute tip and the lower end is in the form of a very rigid curved foot. Considering these variations in morphology and considering also literature data collected for plant fibres, such as flax fibres (showing significant variations in biochemical, morphological and mechanical as function of the position of the fibres along the length of the stem (Charlet el al., 2007), only the central portion of the leaf were investigated in this work. According to Dallel, (2012), the extremities of the leaf contain fine fibres and nodes.

\subsubsection{Retting in saltwater}

The retting process, naturally occurring on the farm or in saltwater by microorganisms (bacteria and fungi), is mainly an enzymatic process, dissolving mainly waxes that protect leaf against unfavourable environmental conditions and insects. The alfa leaves were retted in saltwater $(35 \mathrm{~g} / 1)$ for two periods of respectively one week and three months to evaluate the effect of retting time on the mechanical properties. After retting treatment, the leaves turn a gray colour and the fibres are easily separated from each other. After that, retted fibres were dried in the open air for 3 days. The retted fibres were combed, by means of a comb formed of steel sharp points $(15 \mathrm{~cm})$ attached to a wooden base, to be thinner and less rigid. The objective of the combing process is to parallelize the fibres and keep only the longest. 


\subsubsection{Alkaline treatment}

Alfa fibre tissue, principally consisting of $43.9 \%$ cellulose, $17.96 \%$ lignin and $27.67 \%$ hemicelluloses (table 2), has been shown to be very sensitive to caustic soda. For example, according to Rokbi et al., (2011), a high concentration of sodium hydroxide can attack the fibres and decrease the mechanical properties. Our aim is to evaluate the effect of chemical treatment (in oven) and the combining thermal treatment and chemical treatment (in an autoclave), on the mechanical properties of alfa fibres. The autoclave process used consists in the compression of the wet fibres in a stainless steel autoclave under 1 bar of hot air $\left(120^{\circ} \mathrm{C}\right)$ for 20 minutes followed by a slow decompression of the system by decrease in temperature.

The concentration of $\mathrm{NaOH}$, the temperature and duration of the treatment are the main parameters that affect the quality of the fibres. The optimisation of these parameters is necessary to maintain the integrity of the mechanical properties of plant fibres.

The concentration of $\mathrm{NaOH}$ was minimised in order to lower the environmental impact of this process step. The rigidity of the treated leaves was determined using an organoleptic method. Results show that the leave have the lowest rigidity when a treatment with $0.25 \mathrm{M}$ of $\mathrm{NaOH}$ and incubation for $2 \mathrm{~h}$ at $120^{\circ} \mathrm{C}$ is used. This qualitative test, with a decrease in rigidity at the leave level, provides evidence of the degradation of the main inter-cellular layers and substances which cements the cell walls of adjoining cells.

After optimisation of these parameters (temperature and time of incubation), the alfa fibres were soaked in $0.25 \mathrm{M}, 0.5 \mathrm{M}$ and $1.0 \mathrm{M} \mathrm{NaOH}+0.5 \% \mathrm{Na}_{2} \mathrm{O}_{5} \mathrm{~S}_{2}$ (as antioxidant) solution (fibre $(\mathrm{g})$ and $\mathrm{NaOH}$ solution (ml) ratio was maintained at 1:50) in the oven for $2 \mathrm{~h}$ at $120^{\circ} \mathrm{C}$ and in the autoclave for $20 \mathrm{~min}$ at $120^{\circ} \mathrm{C}$ with a pressure of $1 \mathrm{bar}$ in order to 
evaluate the effect of sodium hydroxide concentration on alfa fibres. The treated fibres were then washed several times with distilled water to remove alkali excess from the fibre surface. The final $\mathrm{pH}$ was maintained at 7.0. The fibres were then dried at $50{ }^{\circ} \mathrm{C}$ for $24 \mathrm{~h}$.

\subsubsection{Enzymatic treatment}

The mechanical and chemical treatments in the present study were conducted to separate the alfa fibre as well as to breakdown fibre bundles in order to enhance the penetration of enzymes solution into fibres.

1.0 gram of fibre was weighed into a $500 \mathrm{ml}$ Erlenmeyer flask. Optimal conditions for each enzymatic reaction were previously studied (table 1). In case of laccase activities, the maximum of phenolic compounds were released at $50^{\circ} \mathrm{C}$ using sodium acetate buffer at 50mMand enzyme concentration 230U/g. For xylanase and pectinase activities, the highest concentration of reducing sugars were observed at $50^{\circ} \mathrm{C}$ when using phosphate buffer $\mathrm{pH} 7$ at $50 \mathrm{mM}$ and citrate buffer $\mathrm{pH} 4.8$ at $50 \mathrm{mM}$ and enzyme concentration $70 \mathrm{U} / \mathrm{g}$ and $5620 \mathrm{U} / \mathrm{g}$ respectively. These optimal conditions are listed in

table 1. For all experiments, the liquid $(\mathrm{ml})$ to fibre $(\mathrm{g})$ ratio was maintained at 150:1 to facilitate complete wetting of fibres. The optimisation of the enzymes reaction time was carried out by treating the fibres at variable time $2 \mathrm{~h}, 4 \mathrm{~h}$ and $8 \mathrm{~h}$.

Fibres were washed with hot water to remove traces of enzyme and buffer reagents. All samples were dried at $50^{\circ} \mathrm{C}$ for $24 \mathrm{~h}$. The amount of reducing sugars released was determined by the dinitrosalicylic acid (DNS) method (Miller, 1959) and the release of phenolic compounds was estimated by measuring the absorption at $\lambda 237 \mathrm{~nm}$.

\section{$2.3 \quad$ Enzymatic assays}

Three enzymes were used in this work, i.e. xylanase, laccase and pectinase. 
The xylanases used for this work are the total extracellular enzymes (commonly named "extracellular juice") produced by the strain AX4 of Talaromyces thermophilus and are completely cellulase-free, as no cellulase activity could be detected at various $\mathrm{pH}$ values and at different enzyme dilutions. The xylanase activity was assayed by measuring the amount of reducing sugars released from Birchwood xylan. The reaction mixture consisted of $500 \mu \mathrm{l}$ of $1 \%$ xylan solution; $400 \mu \mathrm{l}$ of $50 \mathrm{mM}$ phosphate buffer, $\mathrm{pH} 7.0$; and $100 \mu \mathrm{l}$ of enzyme solution. After incubation at $50^{\circ} \mathrm{C}$ for $10 \mathrm{~min}$, the liberated reducing sugars were measured by the DNS method (Miller, 1959). One unit was defined as the amount of enzyme that releases $1 \mu$ mol xylose equivalents min- ${ }^{1}$ under the assay conditions (Maalej et al., 2012).

Laccase activity was determined by the oxidation of 2, 2'-azino-bis (3ethylbenzthiazoline-6- sulfonic acid) (ABTS; SIGMA, St. Louis, USA) at $37^{\circ} \mathrm{C}$ according to Buswell et al., (1995). The reaction mixture (1 mL) contained $600 \mu \mathrm{L}$ enzyme extract, $300 \mu \mathrm{L}$ sodium acetate buffer $\mathrm{pH} 5(0.1 \mathrm{M})$ and $100 \mu \mathrm{L}$ ABTS solution ( $1 \mathrm{mM})$. Oxidation was followed via the increase in absorbance at $420 \mathrm{~nm}\left(\varepsilon_{420}=\right.$ 36,000 M-1. cm-1). One unit of enzyme activity was defined as the amount of enzyme oxidizing $1 \mathrm{mmol}$ of ABTS per minute.

The pectinases were produced by the mutant CT1 of Penicillium occitanis (Hadj Taieb et al., 2002). This mutant is a hyper producer of pectinases only. At $\mathrm{pH} 4.8$, it secreted massively and exclusively exopectinases (mainly polygalacturonases, polymethylgalacturonases and, at a lesser extent, pectin esterases) (Ben Romdhane et al., 2013). Total exo-pectinases activities in the extracellular juice were assayed by the quantification of the reducing sugars liberated by the appropriate enzyme dilution that was mixed with $0.5 \mathrm{ml}$ of $2 \%$ polygalacturonic acid (Sigma) as substrate and $0.5 \mathrm{ml}$ citrate buffer pH4.8 and incubated for $30 \mathrm{~min}$ at $50{ }^{\circ} \mathrm{C}$ (Aguilar \& Huitron, 1990). One 
unit (UI) of exo-pectinolytic activity was defined as the amount of enzyme that liberated one micromole of galacturonic acid per minute.

The enzymes were produced locally in the Laboratory of Valorization of Biomass and Production of Proteins in Eucaryotes (LVBPPE) Centre of Biotechnology of Sfax (CBS).

\section{$2.4 \quad$ Weight loss}

The weight changes of the fibres after alkali treatment were determined by weight loss (\%) calculated according to Ray \& Sarkar (2001) and Sinha \& Rout (2008) as following (Eq.1):

Weight loss $(\%)=\left[\left[\left(\mathrm{W}_{2}-\mathrm{W}_{1}\right) / \mathrm{W}_{1}\right] \times 100\right.$

Where $\mathrm{W}_{1}(\mathrm{~g})$ is the weight of dry fibre before alkali treatment and $\mathrm{W}_{2}(\mathrm{~g})$ is the weight of dry fibre after alkali treatment. Each experiment was repeated three times so that we could study variability.

\subsection{Surface and morphological properties of the isolated fibres}

\subsubsection{Fibre diameter}

Fibres were manually separated from treated and untreated fibre bundles using tweezers. The apparent diameter of the fibres was measured by an optical microscope (Nikon Eclipse LV 150). In general, plant fibres show a complex polygonal-like external shape and have a non-uniform thickness. However, in this work and to simplify the analysis, each fibre was considered as perfectly cylindrical. This hypothesis is formulated by many authors when working on plant fibres (Placet et al., 2014, Rosa et al., 2010 and Alix et al., 2012). The average diameter of each fibre was taken at three different regions with three measurements for each region. 30 samples were used for diameter determination. 


\subsubsection{SEM observation}

The surface topography of alfa fibres was qualitatively investigated to evaluate the influence of the treatments on the fibre surface. This study was performed using a Jeol840 scanning electron microscope. The fibres were extracted from untreated and treated fibre bundles, coated with a thin layer of gold in a Jeol-JFC1100 Sputter Coater and scanning electron micrographs of fibres were recorded.SEM was also used to investigate the morphology of the alfa leaves. The leaves were embedded in an epoxy resin and the cross section of the leaves was polished and observed.

\subsection{Chemical analysis of substrate}

The untreated and treated fibres were milled into small particle size that can pass through $2.0 \mathrm{~mm}$ pore-size sieve for chemical composition analysis.

The initial chemical content of the alfa fibres was characterized starting with the extraction method prior to holocellulose, $\alpha$-cellulose and the Klason lignin test.

Dry weights were determined by oven drying a sample of the feedstock for $48 \mathrm{~h}$ at $100^{\circ} \mathrm{C}$, according to the NREL protocol for determining total solids in biomass, LAP001 (Sluiter \& National Renewable Energy, 2008). Acid insoluble lignin content (Klason Lignin) was determined by a modified version of the method described in TAPPI T222, for acid-insoluble lignin in wood and pulp (TAPPI, T-222, 1988), by two-stage sulfuric acid hydrolysis. The holocellulose content was carried out following the appropriate ASTM D 1104-56. ASTM D 1103-60 was used to estimate the $\alpha$-cellulose content of the different fibre samples. The hemicelluloses content was obtained by subtracting the $\alpha$-cellulose rate from the holocellulose content.

The chemical composition of the alfa fibres was determined before and after each pretreatment process. All analyses were carried out on a dry weight basis (Sluiter, Ruiz, Scarlata, Sluiter, \& Templeton, 2010). 


\subsection{Tensile characterization}

A dynamic mechanical analyser (DMA Bose Electroforce 3230) was used to perform the tensile tests. Longitudinal mechanical properties (Young's modulus, ultimate strength and failure strain) of isolated alfa fibres were determined. Due to the limited fibre length, a gauge length of $10 \mathrm{~mm}$ was chosen. The paper frame supporting each fibre was clamped onto the testing machine (figure3), and was cut before initiating each test (Placet et al., 2014). The applied force is measured using a $2-\mathrm{N}$ load sensor, with a resolution of approximately $1 \mathrm{mN}$, and the displacement was measured using a LVDT with a resolution ranging from 0.1 to $1 \mu \mathrm{m}$. The fibre strain was determined using the displacement measurements and the initial length of the fibre, the tensile stress was determined using the cross-section of each fibre and the Young's modulus was computed from the initial linear section of the stress-strain curve. The cross-section area of the fibre was approximated using the average diameter and considering the fibre as perfectly cylindrical.

\section{$2.8 \quad$ Statistical analysis}

All experiments were replicated at least 20 times and results were expressed as mean value \pm standard deviation. The data were statistically analyzed using Minitab software, Version 16. To identify significant differences between mean values for control and a given extraction method, Mann-Whitney Test was applied to the data populations involved, with a 95\% confidence level $(\mathrm{P}<0.05)$.

An analysis of variance followed by multiple comparison de Tukey-Kramer (with $\alpha=$ 0.05) was performed between the means of untreated and treated sample for each measured parameter (cellulose, hemicelluloses and lignin) (Dagnelie, 2006). 


\section{Results and discussion}

\subsection{Morphological investigation of alfa leaf}

There is very little data available in literature that describes the morphology of alfa plant. Microscopic observations of the transverse and longitudinal cross-sections of the leaf were used to better describe and clarify the anatomy of this plant.

Alfa leaves were observed with a scanning electron microscope. Cross sections (A) as well as longitudinal views (B) at different magnifications are shown in figure 4 . The cross section highlights the internal structure of the alfa leaf. Indeed, it clearly shows the presence of a non-rectilinear hole inside the leaf (figure 4(A1)): alfa leaves have a tube shape that may be opened or closed up longitudinally as a function of the relative humidity of the atmosphere. Microscopic observations with larger magnifications show the structure and organisation the cells and cell walls in the different region of the leaf. The long fibres, under investigation in this work, are located on the periphery of conducting tissues of the leaf, as in flax and hemp stem (Charlet, 2008; Bodros \& Baley, 2008). Furthermore, each ultimate cell is roughly cylindrical or polygonal in its external shape, with a central lumen like other natural plant fibres, as shown in figure 4 (A2). The wall layer is thick and the lumen is roughly filled. The external fibre diameter varies from $5 \mu \mathrm{m}$ to $14 \mu \mathrm{m}$. The middle lamellae have a particularly large thickness. Longitudinal view shows a very peculiar structure homogeneously distributed along the leaf: trichomes (figure $4(\mathbf{B})$ ). The presence of many trichomes on the adaxial side prevents the evaporation of water. An inorganic material was observed at the surface of these trichomes (figure 4(B1)). As reported by Ben Mabrouk (2012) using EDX-SEM this inorganic composition is mainly formed of silica. This morphological study underlined that alfa leaf exhibit a specific structure and is composed of different types of cells. 


\subsection{Influence of alkali treatment}

Alkaline treatment is one of the most common chemical methods used to remove a certain amount of lignin, wax and oils covering the external surface of the fibre cell wall. The important modification achieved with alkaline treatment is the disruption of the hydrogen bonding in the network structure (Faruk et al., 2012). Ramie fibres (Qin et al., 2008), green coconut fibres (Brigida et al., 2010), sisal (Iannace et al., 2001), jute (Mohanty et al., 2000) and coir (Rout et al., 2001) fibres were alkalized and their properties evaluated by several authors in literature.

Figure 5 shows the increase in weight loss of alfa fibres with increasing concentrations of $\mathrm{NaOH}$. The weight loss of the Alfa fibres after alkali treatment in the oven and in the autoclave, results in the partial removal of non-cellulosic components (pectin, hemicellulose and lignin) (Sinha et al., 2008).Generally, more the weight loss is, more the fibre surface is clean.

As shown in figure 5, the increase of the weight loss of the autoclave treatment is greater than the fibres treated in the oven. The autoclave has given more access to the penetration of chemicals thus better removal of non-cellulosic components.

\subsection{Effectiveness of enzymatic treatments by sugar analyses}

The CT1 mutant of Penicillium occitanis and the AX4 strain of Talaromcyes thermophilus are very useful strains which produce juices, extremely rich in specific activities (respectively pectinases and xylanases) without need for purification.

The optimisation of enzymatic hydrolysis conditions is a necessary step for the maximal removal of non-cellulosic components and preservation of fibre characteristics.

The reducing of sugars after enzymatic treatments (xylanase and pectinase) was measured by the DNS method to 550nm (Miller, 1959) using a visible spectrophotometer. The results clearly showed that these enzymes were able to attack 
the alfa fibres tissues. For xylanase and pectinase enzymes, the degree of hydrolysis increases as a function of the incubation period as shown in figure $\mathbf{6}$. The best results were observed in the case of the treatment for 8 hours where the reducing sugars are higher. Besides that, xylanase of T.thermophilus was efficient in liberating reducing sugar from alfa fibres $\left(526 \mathrm{mg} \mathrm{g}^{-1}\right)$. Figure $6 . \mathrm{b}$ shows that very slight effect occurs from $2 \mathrm{~h}$ to $4 \mathrm{~h}$ of treatment. Since during $2 \mathrm{~h}$ and $4 \mathrm{~h}$ there is no significant release of reducing sugars. Therefore, reducing sugars cannot be quantified. They were observed only after 8 hours of reaction. This result may be related to the time required ( $4 \mathrm{~h}$ to $6 \mathrm{~h}$ ) to destroy the three dimensional structure by swelling of the fibre and that facilitated the enzyme penetration into the fibre and attack the hemicellulose polymer.

After laccase treatment, the filtrate was introduced into a quartz cuvette and the absorbance was measured between 200 and $400 \mathrm{~nm}$ using a UV spectrophotometer (Maalej et al., 2012). In the case of laccase, the UV spectrophotometer method is best adapted for determining the concentration of lignin in the wood (Jingjing Li, 2011). The peak at $280 \mathrm{~nm}$ in the UV spectrum underlines the presence of lignin that released coloured compounds after the enzymatic treatments (Nissen et al., 1992). The band at $278 \mathrm{~nm}$ is produced by the aromatic rings in guaiacyl lignin, whereas the strong band at $315 \mathrm{~nm}$ is typical of hydroxycinnamic acids linked to the lignin and/or the arabinomethylglucurono- xylan backbones often found in grasses (Siqueira et al, 2011). The laccase treatment gave absorption of 3.4 after $8 \mathrm{~h}$ reaction (figure 7).This level of absorption was higher than when the alfa fibres treated for $2 \mathrm{~h}$ and $4 \mathrm{~h}$.

After optimisation of the incubation time, the fibres were treated by the three enzymes (laccase, pectinases and xylanases) successively. When alfa fibres were treated with enzymes, the colour removal increased (figure 8). The colour change is an effective indication of the removal of ligneous components. It can be observed that treatment 
with laccase was more efficient on the color removal compared to other enzymes. Furthermore, laccase treatment could be bleaching process through its ability to oxidize substances lignin. Fjellstrom (2008) reported that there exists a strong correlation between lignin content and the degree of discolouration, regardless of the wood raw material or bleaching method used.

\subsection{Impact of the various treatments on the surface topology of technical fibres and on} $\underline{\text { the degree of separation of fibres }}$

Morphological changes of treated fibres were examined by SEM to qualitatively evaluate the structural modification of the surface. Figure 9 highlights the evolution of alfa fibres surface at different stage of treatment and the degree of separation of single fibres. It can be seen from the images that the surface treatment process gently cleaned the fibre's surface without showing any indication of fibre damage.

The surface of retted fibres, shown in figure 9 (a) and (b) present a surface covered with waxes fats and polysaccharides. As illustrated in figure 9 (c) and (d) the cementing materials (such pectin and lignin) present on the surface of fibres, were eliminated with $\mathrm{NaOH}$ treatment. Some cementing materials can, however, be noticed. Due to the elimination of the cementation material, the surface becomes smoother and the fibrillation has become much easier.

Figure 9 shows also the fibre surface obtained after the enzymatic treatment using respectively laccase (e), pectinases (f) and xylanases (g). For the fibres treated with laccase, the cellulose microfibrils are visible, which indicates that the lignin and other non-cellulosic materials are greatly removed from the fibre surface (figure $\mathbf{9 ( e ) )}$ ). Moreover, the surface was rough and this can be an advantage for the fibre-matrix interface. 
The morphological changes of the treated fibres with pectinase and xylanase showed similar pattern as represented in figure 9 (f) and (g). Pectinase treatment was the most effective for separating alfa fibres into smaller bundles and single fibre (figure 9 (f)). Alfa fibers treated with pectinase allowed a better separation of the fibres due to removal of material from the fibre surface and possibly as a result of the degradation of polygalacturonan, a major component of pectin found predominantly in the primary cell wall (Bateman and Basham, 1976).

As the biological glue was hydrolysed, the other non cellulosic components of the primary wall are released and dissolved by the surfactants and mild chelating agents in the biopreparation bath (Sawada et al., 1998). As shown in figure 9 (g), xylanase treatment is also effective for the separation of alfa fibres. Xylanases cleave and solubilise reprecipitated xylan and lignin located on the surface of the microfibrils (Prade, 1996). In addition, Yang and Eriksson (1992) report the release of lignincarbohydrate complexes by xylanase treatments of kraft pulps.

\subsection{Chemical Analysis}

The results on general chemical composition of untreated alfa fibres considered in this study are presented in Table 2 . Table 2 shows the mean and standard deviations of three replicate determinations of each sample.

The percentage of cellulose, hemicelluloses and lignin present in untreated fibre is $43.9 \%, 27.67 \%$ and $17.96 \%$ respectively. This conforms to earlier reports in literature (Harche \& Bounaga, 1979 and Hamza et al., 2013).

The amount of the different fibre components quantified (Table 2) does not add up to $100 \%$, simply because only the major components are reported. We did not determine the amount of pectin, pentosan and proteins as well as the extractable organic matter, such as waxes, fatty alcohols, fatty acids and different esters (Ribitsch et al. 1996). 
The proportions of cellulose, hemicellulose and lignin fractions present in the retted and unretted fibre were significantly different. The lignin and hemicellulose contents were proportionally lower in the retted fibre compared with the untreated fibre (Table 2). This indicated that the gummy materials, i.e., lignin and hemicellulose, could be removed by the saltwater-retting treatment as shown by George et al (2014).

As shown in table 2, the time retting has a significant effect on the removal of lignin and hemicelluloses. This emphasized the importance of retting parameters on the chemical composition of retted fibres as well as its mechanical properties.

Moreover, it is clear from figure 5 that treatment with sodium hydroxide results in maximum removal of non-cellulosic material from alfa fibres and the enzymatic treatments slightly enhance this further.

The treatment with sodium hydroxide is also found to be efficient in delignification of alfa fibre (9\% of lignin removal) and the hemicellulose of alkali treated fibres was much lower than those obtained for untreated fibre. Table 2 shows that around $65.5 \%$ of hemicelluloses were removed.

Autoclave pretreated fibres underwent a removal of hemicellulose more than $86 \%$, which remained only $3.5 \%$, whereas oven pretreated fibre still retained a good hemicellulose content of $8.7 \%$. Nevertheless, alkali treatment in the autoclave was more capable of removing lignin then alkali treatment in the oven, wherein it removed about $32.1 \%$ of the lignin content. It was noted that the autoclave pretreated fibre experienced better hemicellulose and lignin elimination than oven pretreated.

Therefore, this removal is already reflected in the figure 5 by the loss of weight in which it was noted that the alkaline treatment in an autoclave allowed a higher weight loss than the alkaline treatment in an oven. 
It was found that the cellulose content of treated fibres was higher than that of the untreated fibre. This occurrence was basically due to the removal of the hemicellulose and lignin, which indirectly increase the percentage of cellulose in fibre.

As shown in table 2, the combination chemical + enzymatic treatment resulted in the most significant removal of non-cellulosic components. Pietak et al., 2007 report that fibres treated with alkaline and enzymatic treatment should have a higher cellulosic component, and thus suggest a more effective removal of the middle lamella and the primary cell wall and therefore a more cellulose rich surface.

Laccase treated alfa fibres were characterized with a significant reduction $(p<0.05)$ in the lignin content (about $28 \%$ of removal lignin) and consequently an increase in hemicellulose content. This is confirmed in figure 7 with the release of the phenolic compounds.

Pectinase treated alfa fibres has removed the pectin as clearly demonstrated in the figure 6 by the release of reducing sugars linked to galacturonic acid and a small amount of lignin as shown in table 2.

The pectin and lignin content are randomly distributed between the primary cell wall and the secondary walls. Hence, the use of pectinase alone was sufficient to remove these exposed components and initial swelling may not be required (Mohanty et al., 2000).

\subsection{Tensile properties of the elementary fibres}

The mechanical properties of alfa fibre are observed to be remarkably dependent on the chemical composition of fibre, as shown in table 2. The untreated alfa fibres were found to have drastically lower tensile properties compared to the retted alfa fibres ( $5 \mathrm{GPa}$ vs. $21 \mathrm{GPa}$ for the apparent tensile modulus, approximately $80 \mathrm{MPa}$ vs. $420 \mathrm{MPa}$ for the ultimate strength and $1.5 \%$ vs. $1.95 \%$ for strain at failure). These large differences can 
be attributed to the damage level resulting from the manual extraction of the fibres using tweezers for the tensile test preparation. Due to the degradation level of inter-cellular layers, it requires lower mechanical force to separate the retted fibres. This difference, particularly in strength, can also be attributed to the size and structure of the tested fibres. Untreated fibres and retted fibres have respectively an average diameter of approximately $157.5 \mu \mathrm{m}$ and $22-30 \mu \mathrm{m}$. It is well-known that the fibre strength decreases with increasing diameter, due to the probability of defect occurrence (Duval et al., 2011). Based on the previous microscopic observations, which show an external fibre diameter from $5 \mu \mathrm{m}$ to $14 \mu \mathrm{m}$, it is also clear that the retted fibres are relatively well individualized contrary to untreated fibres which are still organized in bundles of fibres. The mechanical properties of fibre bundles are generally lower than single fibres due to the limited strength of middle lamellae.

The obtained value of average diameter (of approximately 22-30 $\mu \mathrm{m}$ ) of tested fibres also clearly indicate that these ones include probably both elementary fibres and small bundles composed of two or three elementary fibres. As it was underlined recently for hemp fibres (Placet et al., 2015), it is particularly difficult using only optical observation of the external surface of the fibre to ensure its single character.

The duration of the retting stage has also a significant $(\mathrm{p}<0.05)$ impact on the mechanical behavior of the fibre. Three months retted fibres have higher mechanical performances than one week retted fibres, with an average modulus of $31 \mathrm{GPa}$, an ultimate strength of $680 \mathrm{MPa}$ and strain at failure of $2.5 \%$. Again, this was attributed to a better elimination of constituents cementing the fibres together. This hypothesis is consistent with the by the decrease in percentages of hemicellulose and lignin as reported in Table 2. 
Additional treatment with sodium hydroxide is showed to be highly valuable from a mechanical point of view, in particular when the treatment is performed using autoclave. The tensile strength and the apparent Young's modulus of alkaline modified fibres increased by $50 \%$ as compared to one week retted fibres.

In order to further verify the effect of different extraction methods on the mechanical properties of alfa fibres, a detailed statistical analysis was also carried out, with the results shown in Table 3. Based on the test results; it is obvious that the extraction methods significantly (at $\mathrm{p} \leq 0.05$ ) influence the mechanical properties of alfa fibres. Thus, we conclude that the mechanical properties of alfa fibres are predominantly affected by extraction methods.

The biochemical analysis allowed us to better understand the effect of alkali treatment on the mechanical properties of the fibre. The fibre quality was evaluated in terms of chemical composition, with focus on cellulose since cellulose is of importance to the fibre strength. As clearly demonstrated in table 2, the alkali treatment attacked a significant proportion of hemicellulose and lignin and on the other an important proportion of cellulose was noticed about $86 \%$ of cellulose vs $43.9 \%$ of cellulose for untreated fibre. The aim of this comparison is to facilitate the understanding of what could be the relationship between fibre composition and tensile properties.

The influence of the additional enzymatic stages on the performance of the alfa fibres are also shown in table 4. If the laccase treatment does not induce a notable variation in mechanical properties, the targeted enzymatic degradation induced by pectinase and xylanase significantly, and differently influences the final mechanical properties of the fibres. The fibres treated with pectinase exhibited remarkably high tensile properties $\left(\mathrm{E}=58 \pm 17.4 \mathrm{GPa}, \sigma_{\mathrm{u}}=1327 \pm 342 \mathrm{MPa}\right.$ and $\left.\varepsilon_{\mathrm{f}}=2.5 \pm 0.64 \%\right)$ close to those reported by (Bessadok et al., 2009).These average values are amongst the highest observed on plant 
fibres (table 5).This makes alfa fibres a high-potential and promising candidate for composite reinforcement, as a substitute of glass fibres. The mechanical properties obtained with xylanase treatment are really valuable for the fibre modulus, which reaches a really high average value of about $66 \mathrm{GPa}$. Xylanase is also observed to induce a decrease in stress and strain at failure. For the enzymatic treatment, there is no significant difference in the rate of cellulose as shown in table 2. Thus, the increase of tensile properties of alfa fibre was not influenced by the rate of cellulose. This increase is due to the percentage decrease of the lignin and the percentage increase of the hemicelluloses.

As shown in figure 9 that after enzymes treatment of alfa fibres, the fibres are more separated and their diameter are reduced. Consequently, the mechanical properties of treated fibres are correlated with the degree of separation of the fibres, the fibre diameters and the chemical composition of separated fibres. It can be also hypothesized that separated fibres could have a better circularity than big bundles of fibres and that this increase in stiffness and strength could be attributed in part to a reduction of the error done when determining the cross-section area of the separated fibres. To confirm this hypothesis, a specific study dedicated to the characterization of the 3D morphology is required.

\section{Conclusions}

In this work, the morphology of the alfa leaf and the effect of various treatments on the mechanical properties of alfa fibres were investigated. The treatments combined saltwater retting, sodium hydroxide and enzymatic treatment. $\mathrm{NaOH}$ treated alfa fibres in the autoclave, showed greater tensile strength and Young's modulus than alfa fibres which were treated in the oven. Within this study, it is also observed that the enzyme treatments yielded high quality fibres that were among the finest and strongest 
produced. As shown in Table 4, the alfa fibres treated with the enzymes gave higher results than those found with the chemically treated fibres. It was also observed that in addition to the preservation of these high-mechanical properties, these treatments also induce a change in the fibre surface and in the chemical composition of fibre. The research in this study can establish a base for future studies to develop commercial grade of alfa fibres for use in composites. This work also showed that enzymes offer an attractive and eco-friendly approach to efficiently extract high-performance plant fibres. The main challenges still remaining to be tackled in order to treat high fibre volumes and also in the optimisation of the whole extraction process in order to decrease the energy-consumption induced by the drying steps.

\section{Acknowledgements}

The authors are grateful for the financial support of the Agence universitaire de la Francophonie (AUF). The authors are also grateful to Christine Millot for carrying out the electron microscopical examinations. The authors thank to Ousseynou Cisse and Mohamed Guerfali for their technical support during the research.

\section{References}

Aguilar, G., Huitron, C., 1990. Constitutive exo-pectinase produced by Aspergillus sp. CH-Y-1043 on different carbon source. Biotechnol. Lett. 12, 655-60.

Akin, DE., Foulk, JA., Dodd, RB., McAliser, III DD., 2001. Enzyme retting of flax and characterization of processed fibres. J Biotechnol. 89, 193-203.

Alix, S., Lebrun, L., Marais, S., Philippe, E., Bourmaud, A., Baley, C., 2012. Pectinase treatments on technical fibres of flax: Effects on water sorption and mechanical properties. Carbohydrate Polymers 87, 177- 185.

Bacci, L., Di Lonardo, S., Albanese, L., Mastromei, G., Perito, B., 2010. Effect of different extraction methods on fibre quality of nettle (Urtica dioica L.). Textile Research Journal. 81, 827-837.

Bateman, D.F., Basham, H.G., 1976. Degradation of plant cell walls and membranes by microbial enzymes. Encyclopedia Plant Physiol. 4, 316-355. 
Belaadi, A., Bezazi, A., Bourchak, M., Scarpa, F., 2013. Tensile static and fatigue behaviour of sisal fibres. Materials and Design 46 , 76-83.

Ben Brahim, S., Ben Cheikh, R., 2007. Influence of fibre orientation and volume fraction on the tensile properties of unidirectional Alfa-polyester composite. Composites Science and Technology. 67, 140-147.

Ben Mabrouk, A.B., Kaddami, H., Boufi, S., Erchiqui, F., Dufresne, A., 2012. Cellulosic nanoparticles from alfa fibres (Stipa tenacissima): extraction procedures and reinforcement potential in polymer nanocomposites. Cellulose $19,843-853$.

Ben Romdhane, Z., Tounsi, H., Hadj-Sassi, A., Hadj-Taieb, N., Gargouri, A., 2013. The constitutive production of pectinase by the CT1 mutant of Penicillium occitanis is modulated by $\mathrm{pH}$. Appled and Biochemical Biotechnology. 169:215227.

Bessadok, A., Roudesli, S., Marais, S., Follain, N. \& Lebrun, L., 2009. Alfa fibres for unsaturated polyester composites reinforcement: Effects of chemical treatments on mechanical and permeation properties. Composites: Part A. 40, 184-195.

Bouiri, B.,Amrani, A., 2010. Elemental chlorine-free bleaching halfa pulp.Journal of Industrial and Engineering Chemistry. 16, 587-592.

Bledzki, AK., Mamun, AA., Jaszkiewicz, A., Erdmann, K., 2010. Polypropylene composites with enzyme modified abaca fibre. Composites Science and Technology. 70, 854-60.

Bodros, E., Baley, C., 2008. Study of the tensile properties of stinging nettle fibres (Urticadioica).Materials Letters 62, 2143 -2145.

Brigida, AIS., Calado, VMA., Gonc, alves LRB., Coelho, MAZ.,2010. Effect of chemical treatments on properties of green coconut fibre. Carbohydrate Polymers $79,832-8$.

Buswell, J.A.,Cai, Y., Chang, S.T., 1995. Effect of nutrient nitrogen and manganese on manganese peroxidase and laccase production by Lentinula (Lentinus) edodes. FEMS Microbiol. Lett. 128, 81-88.

Charlet. C.,2008. Contribution à l'étude de composites unidirectionnels renforcés par des fibres de lin relation entre la microstructure de la fibre et ses propriétés mécaniques. Caen: Université de Caen Basse Normandie.

Charlet,K., Baley,C., Morvan,C., Jernot, J.P., Gomina,M., Breard,J., 2007. Characteristics of Herme`s flax fibres as a function of their location in the stem and properties of the derived unidirectional composites. Composites: Part A 38. 1912-1921.

Dallel, M., 2012. Evaluation du potentiel textile des fibres d'Alfa (Stipa Tenacissima L.): Caractérisation physico-chimique de la fibre au fil. pp. 141. Haute-Alsace, Mulhouse. 
Dagnelie P., 2006. Statistiques théoriques et appliquées. 2. Inférence statistique à une et à deux dimensions. 2e éd. Bruxelles : Éditions De Boeck.

Duval, A., Bourmaud, A., Augier, L.,Baley, C., 2011. Influence of the sampling area of the stem on the mechanical properties ofhemp fibres. Materials Letters $65797-$ 800 .

Faruk, O., Bledzki, A.K., Fink, H.P., Sain, M., 2012. Biocomposites reinforced with natural fibres: 2000-2010. Progress in Polymer Science. 37, 1552-1596.

Fjellström, H., 2008. Inhibition of light-induced colour reversion of wood-containing papers by means of coating.

Frederiksen, P.S., 1969. Studier over Markrodning af her med Smrlig Henblik pii Mycologiskfermentation I-II, (Mycological Investigations of Field Retting of Fibre Flax). Beretning nr. 43. Forskningsinstituttet for Handels- og Industriplanter, Kolding.

George, M., Mussone, P.G., Bressler, D.C., 2014. Surface and thermal characterization of natural fibres treated with enzymes. Industrial Crops and Products 53, 365373.

Hadj-Taieb N., Ayadi, M., Trigui, S., Bouabdallah, F., Gargouri, A., 2002. Hyperproduction of pectinase activities by a fully constitutive mutant (CT1) of Penicillium occitanis. Enzymes and Microbial Biotechnology. 30, 662-666.

Hamza, S., Saada, H., Charrier, B., Ayeda, N., C-El Bouhtoury, F., 2013. Physicochemical characterization of Tunisian plant fibers and its utilization as reinforcement for plaster based composites. Industrial Crops and Products. 49, $357-365$.

Harche M., Bounaga D., 1979. Etude comparative du tissu fibreux dans la feuille d'alfa « Stipa tenacissima L. », Bull Soc. - Hist. Nat. Alger., 113-120.

Hoondal, GS., Tiwari, RP., Tewari, R., Dahiya, N., 2002. Microbial alkaline pectinases and their industrial applications: a review. Appl Microbiol Biotechnol. 59, 409418.

Iannace, S., Ali, R., Nicolais, L.,2001. Effect of processing conditions on dimensions of sisal fibres in thermoplastic biodegradable composites. Journal of Applied Polymer Science. 79, 1084-91.

Jahan, M.S. \& Mun, S.P., 2007. Characteristics of dioxane lignins isolated at different ages of Nalita wood (Trema orientalis). Journal of Wood Chemistry and Technology. 27, 83-98.

Jingjing, L., 2011. Isolation of Lignin from Wood, Saimaa University of Applied Sciences, Imatra Unit of Technology, Degree Programme in Paper Technology Bachelor's Thesis. 
Kashyap, DR., Vohra, PK., Chopra, S,. Tewari, R., 2001. Applications of pectinases in the commercial sector: a review. Bioresource Technol. 77, 215-227.

Lefeuvre, A.,Bourmaud, A., Morvan, C.,Baley, C., 2014. Tensile properties of elementary fibres of flax and glass:Analysis of reproducibility and scattering. Materials Letters 130 , 289-291.

Liu, L., Cheng, L., Huang, L., Yu, J., 2012. Enzymatic Treatment of Mechanochemical Modified Natural Bamboo Fibres. Fibres and Polymers. 13, 600-605.

Maalej-Achouri, I., Guerfali, M., Belhaj-Ben Romdhane, I., Gargouri, A., Belghith, H., 2012. The effect of Talaromyces thermophilus cellulase-free xylanase and commercial laccase on lignocellulosic components during the bleaching of kraft pulp, International Biodeterioration \& Biodegradation. 75, 43-48.

Mahjoub, R., Yatim, J.M., Mohd Sam, A.R., Hashemi, S.A., 2014. Tensile properties of kenaf fibre due to various conditions of chemical fibre surface modifications. Construction and Building Materials 55, 103-113.

Marrot, L., Lefeuvre, A., Pontoire, B., Bourmaud, A., Baley, C., 2013. Analysis of the hemp fibre mechanical properties and their scattering (Fedora 17). Industrial Crops and Products 51,317-327.

Mehdadi, Z., Benaouda, Z.,Belbraouet, S., Benhassaini, H., Hamel, L., Benali, M., 2000. Évolution saisonnière de la composition foliaire de Stipa tenacissima L. en lipides totaux et en acides gras.

Method of test for holocellulose in wood, USA, ASTM D 1104-56, 1978.

Miller, G.L., 1959. Use of dinitrosalicylic acid reagent for determination of reducing sugar. Analytic Chemistry. 31, 426-428.

Mohanty, AK., Khan, MA., Misra. M., Hinrichsen, G., 2000. Natural fibre reinforced biodegradable matrix composite: effect of surface modification of jute on the performance of jute biopol composites. PMSE Preprints. 82, 29-30.

Mohanty, A.K., Misra, M., Hinrichsen, G., 2000. Biofibres, biodegradable polymers and biocomposites: an overview. Macromol. Mater. Eng. 276 (3-4), 1-24, http://dx.doi.org/10.1002/(SICI)1439-2054(20000301)276:1 3.0.CO;2-W.

Nissen, A.M., Anker, L., Munk, N., Lange, N.K., 1992. Xylanase for the pulp and paper industry. In: Visser, J., Beldman, G., Kustersvan someren, M.A., Voragen, A.G.J. (Eds.). Programm Biotechnology. 7, 325-337.

Osorio, L., Trujillo, E., Van Vuure, A.W., Verpoest, I.,2011. Morphological aspects and mechanical properties of single bamboo fibres and flexural characterization of bamboo/ epoxy composites. Journal of Reinforced Plastics and Composites $.30,396-408$.

Pietak, A., Korte, S., Tan, E., Downard, A., \& Staiger, M. P., 2007. Atomic force microscopy characterization of the surface wettability of natural fibres.Applied Surface Science, 253(7), 3627-3635. 
Prade, R.A., 1996. Xylanases: from Biology to BioTechnology. Biotechnology and Genetic Engineering Reviews 13, 101-

132.doi:10.1080/02648725.1996.10647925

Placet, V., Cissé, O., Boubakar, L., 2014.Nonlinear tensile behaviour of elementary hemp fibres. Part I: Investigation of the possible origins using repeated progressive loading with in situ microscopic observations. Composites: Part A 56, 319-327.

Placet, V., Méteau, J., Froehly, L., Salut, R., Boubakar, ML, 2015. Investigation of the internal structure of hemp fibres using Optical Coherence Tomography and Focused Ion Beam transverse cutting. Journal of Materials Science, 49:83178327

Qin, C., Soykeabkaew, N., Xiuyuan, N., Peijs, T.,2008. The effect of fibre volume fraction and mercerization on the properties of all-cellulose composites. Carbohydrate Polymers. 71, 458-67.

Ray, D., Sarkar, B.K., 2001. Characterization of alkali-treated jute fibres for physical and mechanical properties. J. Appl. Polym. Sci. 80, 1013-1020.

Ribitsch V., Stana-Kleinschek K. and Jeler S. 1996. The influence of classical and enzymatic treatment on the surface charge of cellulose fibres. Colloid Polym. Sci. 274(4): $388-394$.

Rokbi, M., Osmani, H., Imad, A., Benseddiq, N., 2011. Effect of Chemical treatment on Flexure Properties of Natural Fibre-reinforced Polyester Composite. Procedia Engineering. 10, 2092-2097.

Rosa, I.M., Kenny, J.M., Puglia, D., Santulli, C., Sarasini, F., 2010. Morphological, thermal and mechanical characterization of okra (Abelmoschus esculentus) fibres as potential reinforcement in polymer composites. Compos. Sci. Technol. 70, $116-122$.

Rout, J., Tripathy, S.S., Nayak, S.K., Misra, M., Mohanty, AK., 2001 Scanning electron microscopy study of chemically modified coir fibres. Journal of Applied Polymer Science. 79, 1169-77.

Sawada, K., Tokino, S., Ueda, M., Wang, X.Y., 1998. Bioscouring of cotton with pectinase enzyme. Journal of the Society of Dyers and Colourists 114, 333-336.

Sharma, H.S.S., 1986. An alternative method of flax retting during dry weather. Ann. Appl. Biol. 109, 605-611.

Sinha, S., Rout, S.K., 2008. Influence of fibre-surface treatment on structural, thermal and mechanical properties of jute. J. Mater. Sci. 43, 2590-2601.

Siqueira, G., MF Milagres, A., Carvalho, W., Koch, G., Ferraz, A., 2011. Topochemical distribution of lignin and hydroxycinnamic acids in sugar-cane 
cell walls and its correlation with the enzymatic hydrolysis of polysaccharides. Biotechnology for Biofuels.4:7.

Sluiter, A., \& National Renewable Energy, L., 2008. Determination of total solids in biomass and total dissolved solids in liquid process samples laboratory analytical procedure (LAP): issue date, 3/31/2008. Golden, CO: National Renewable Energy Laboratory.

Sluiter, J. B., Ruiz, R. O., Scarlata, C. J., Sluiter, A. D., \& Templeton, D. W., 2010. Compositional analysis of lignocellulosic feedstocks 1 . Review and description of methods. Journal of Agricultural and Food Chemistry, 58(16), 9043-9053.

Standard test method for $\alpha$-cellulose, USA, ASTM D 1103-60, 1978.

Tappi Method T 222 om-88. (1988). "Acid-insoluble lignin in wood and pulp," TAPPI PRESS, Atlanta, GA.

Van Sumere, C.F., 1992. Retting of flax with special reference to enzyme-retting. In: Sharma, H.S.S., Van Sumere, C.F. (Eds.), The Biology and Processing of Flax.MPublications, Belfast, Northern Ireland, pp. 157-198.

Yang, J.L., Errikson K.E.L., 1992. Use of hemicellulolytic enzymes as one stage in bleaching of kraft pulps. Holzforschung 46,481-488.

Zeriahène N., 1987. Étude du système racinaire de l'alfa en relation avec l'adaptation au xérophytisme. Thèse de magister, Institut des sciences de la nature, Oran.

\section{Figures captions}

Figure 1.Representative diagram of the selected and tested strategies for the fibres separation and extraction.

Figure 2. Variation of the diameter along the length of the leaf.a. optical picture. $b$. measurement performed on 7 leaves every $5 \mathrm{~cm}$ along the length.

Figure 3.The protocol tensile test of single fibres.

Figure 4.SEM observations of Alfa leaf: cross section views (A) and longitudinal views (B) at different magnifications.

Figure 5.Evaluation of weight loss after the alkali treatment in the oven and in an autoclave. 
Figure6.Optimisation of time for enzymatic treatment: (A) pectinase and (B) xylanase.

Figure 7. UV spectrum of coloured compounds released during enzyme treatment for different incubation times.

Figure 8.Photograph of the treated fibres. (a) $\mathrm{NaOH}$ treated fibres, (b) xylanase treated fibres, (c) pectinase treated fibres and (d) laccase treated fibres.

Figure 9.Microscopic observation of (a) retted fibres for 1 week, (b) retted fibres for 3 months, (c) alkaline treated fibres in the oven, (d) alkaline treated fibres in the autoclave, (e) laccase treated fibres, (f) pectinase treated fibres and (g) xylanase treated fibres.

\section{Tables captions}

Table 1.Characteristics of each enzyme system with corresponding activity at optimum conditions.

Table 2. Chemical composition of the treated fibres with respect to cellulose, hemicellulose and lignin.

Table 3. Mechanical properties of alfa fibres for each defibration step.

Table 4.Mechanical properties of alfa fibres according to the literature.

Table 5.Comparison of mechanical properties of different natural fibres 
Figure 1.Representative diagram of the selected and tested strategies for the fibres separation and extraction

\section{The Alfa leaves were harvested and dried}

Salt water retting for 3 months
Salt water retting for a week

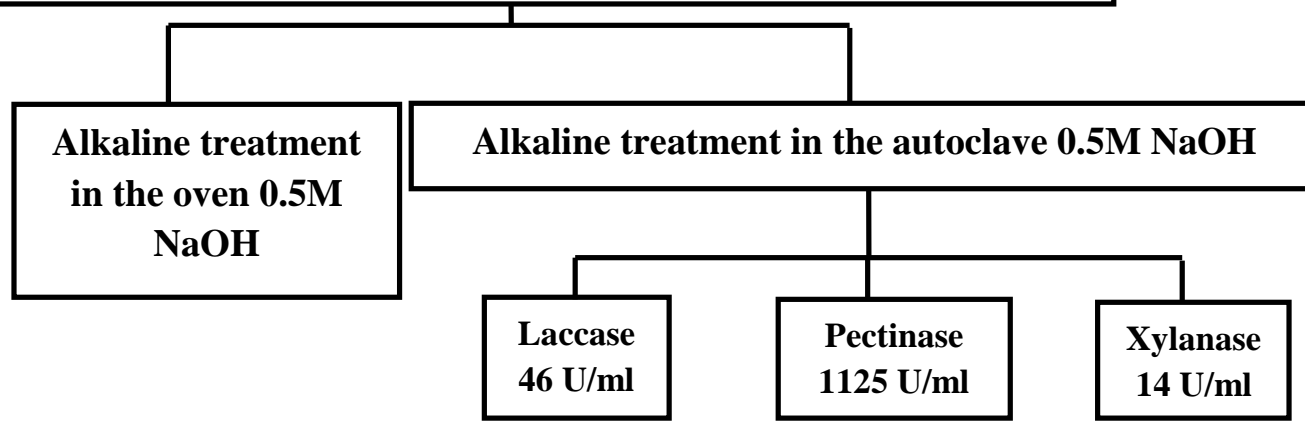

Figure 2.Variation of the diameter along the length of the leaf. a. optical picture. $b$. measurement performed on 7 leaves every $5 \mathrm{~cm}$ along the length

a.

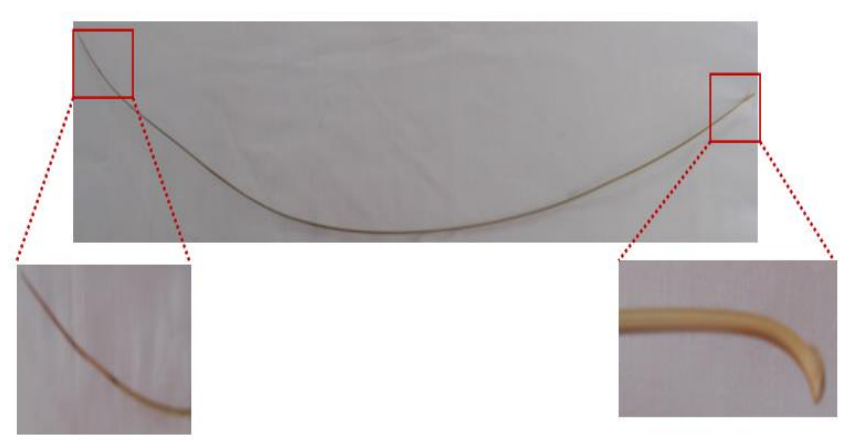

b.

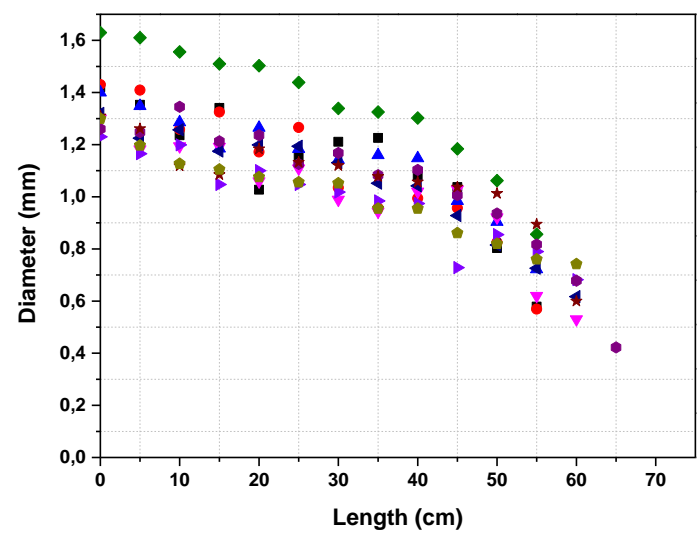

Figure 3.The protocol tensile test of single fibres
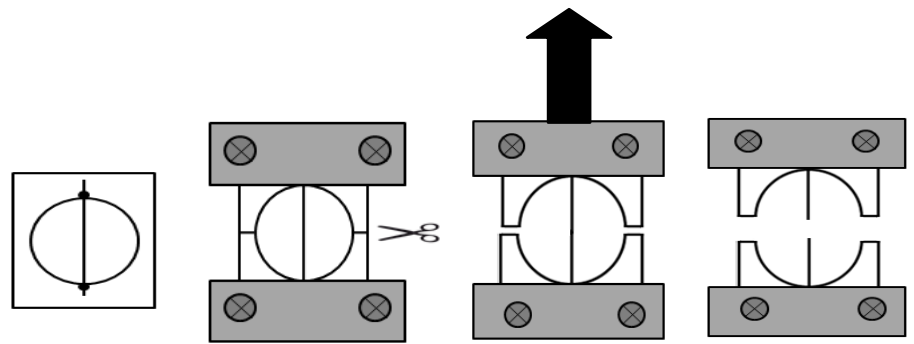
Figure 4.SEM observations of Alfa leaf: cross section views (A) and longitudinal views (B) at different magnifications.
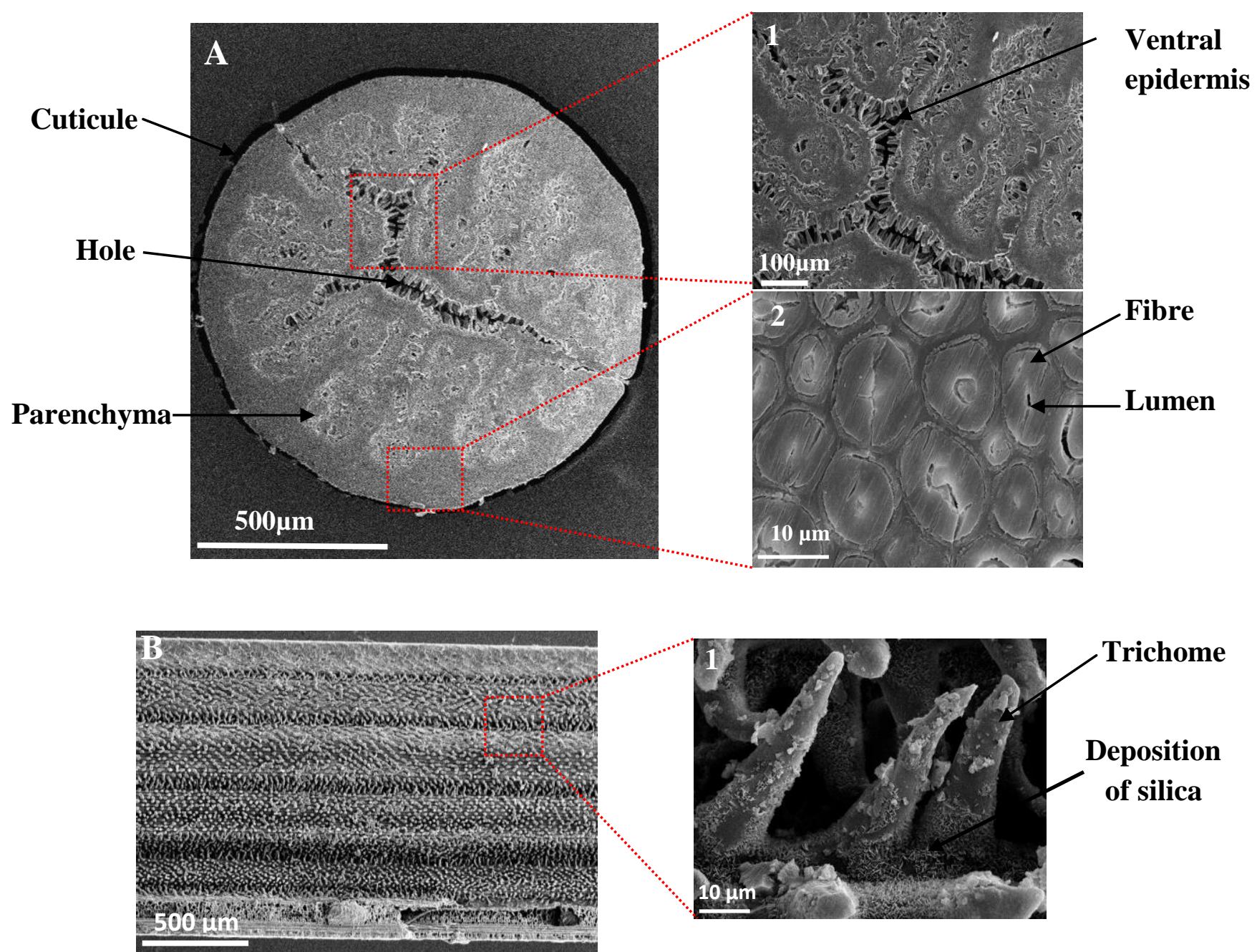

Figure 5.Evaluation of weight loss after the alkali treatment in the oven and in an autoclave

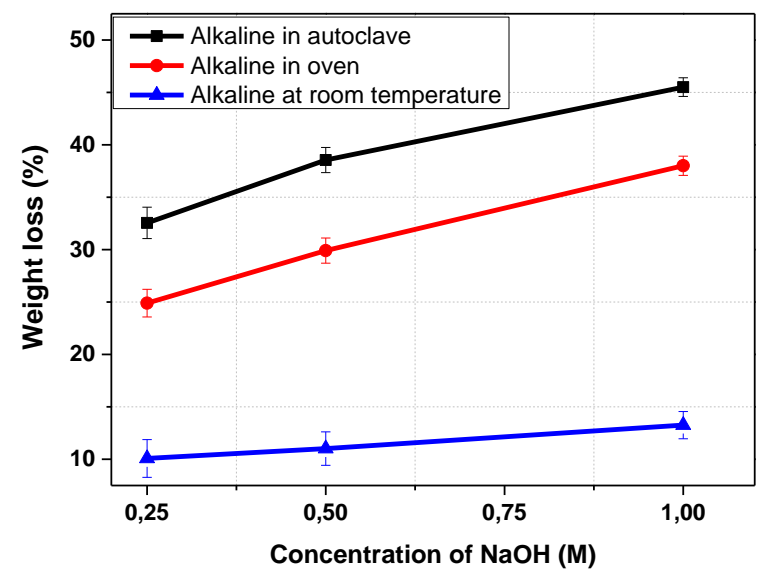


Figure 6.Optimisation of time for enzymatic treatment: (A) pectinase and (B) xylanase

A

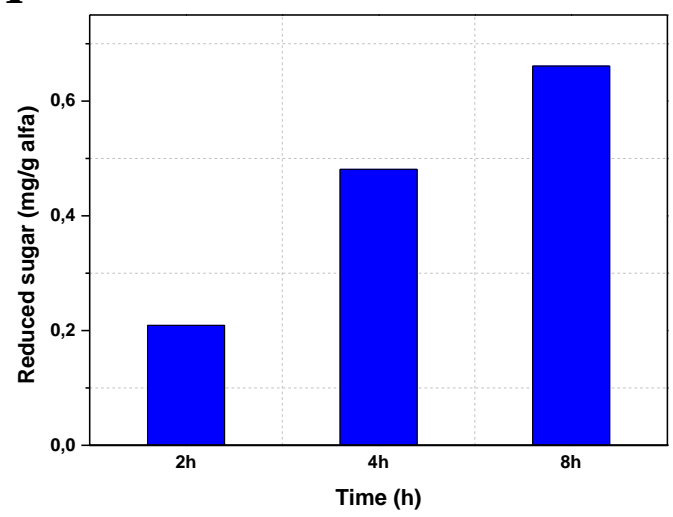

B

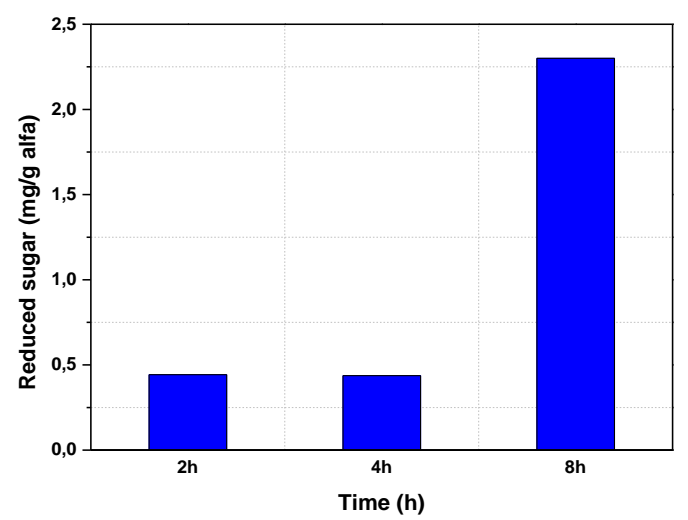

Figure 7.UV spectrum of coloured compounds released during laccase treatment for different incubation times

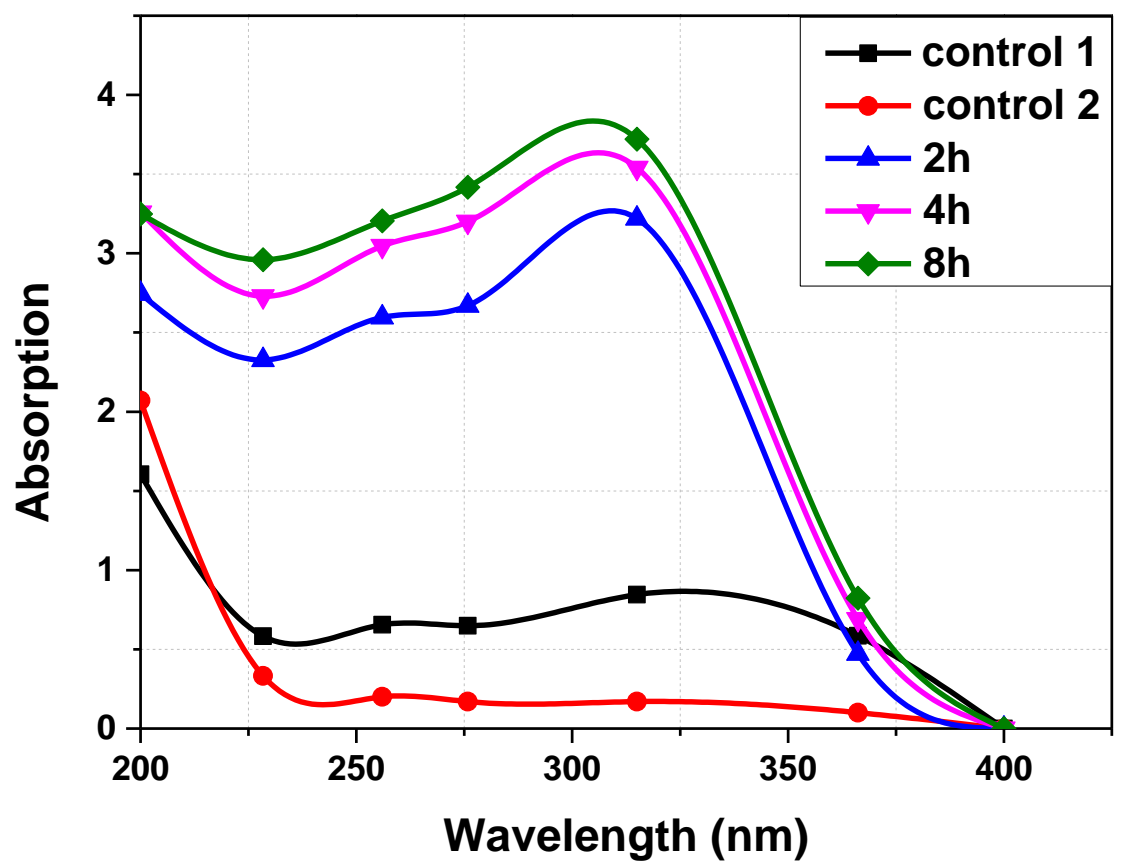

Control 1 samples were treated under the same condition (at time $2 \mathrm{~h}$ ) without the addition of laccase. Control 2 samples were treated with laccase at time $0 \mathrm{~h}$. 
Figure 8.Photograph of the treated fibres. (a) $\mathrm{NaOH}$ treated fibres, (b) xylanase treated fibres, (c) pectinase treated fibres and (d) laccase treated fibres

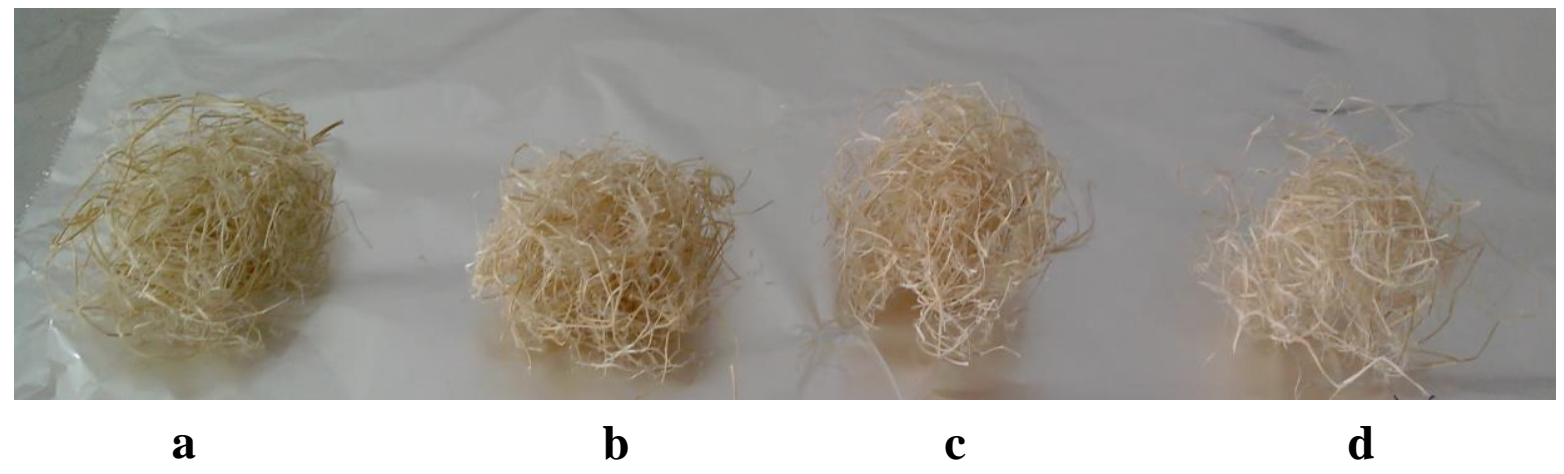


Figure 9.Microscopic observation of (a) retted fibres for 1 week, (b) retted fibres for 3 months, (c) alkaline treated fibres in the oven, (d) alkaline treated fibres in the autoclave, (e) laccase treated fibres, (f) pectinase treated fibres and (g) xylanase treated fibres
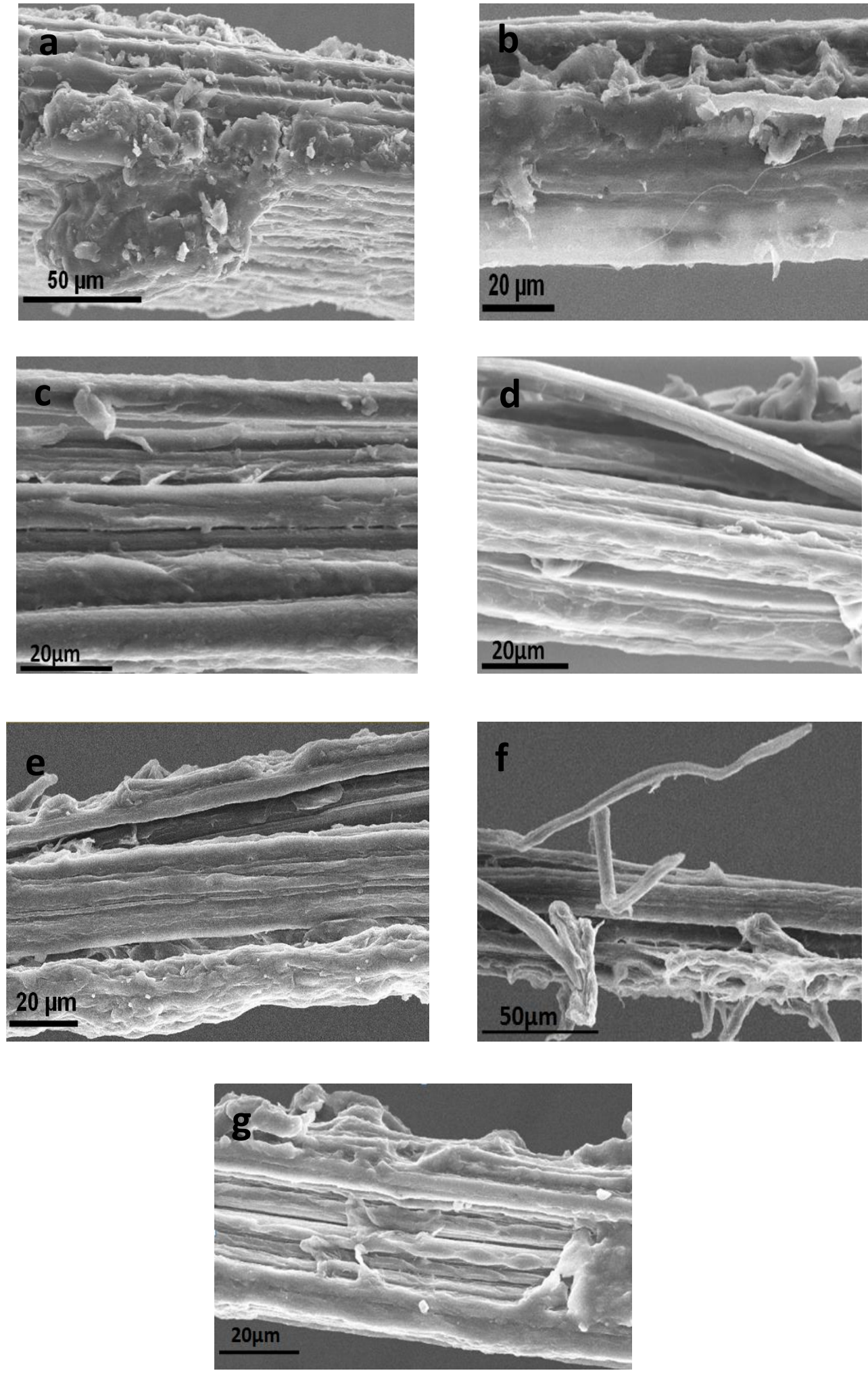
Table 1.Characteristics of each enzyme system with corresponding activity at optimum conditions

\begin{tabular}{ccccc}
\hline Enzyme & \multicolumn{4}{c}{ Optimum conditions } \\
\hline & $\mathbf{p H}$ & Temperature $\left({ }^{\circ} \mathbf{C}\right)$ & Buffer & Activity \\
\hline Laccase & 5 & 50 & $\begin{array}{c}\text { Sodium acetate } \\
50 \mathrm{mM}\end{array}$ & $230 \mathrm{U} / \mathrm{g}$ \\
\hline Pectinase & 4.8 & 50 & Citrate $50 \mathrm{mM}$ & $5620 \mathrm{U} / \mathrm{g}$ \\
\hline Xylanase & 7 & 50 & Phosphate $50 \mathrm{mM}$ & $70 \mathrm{U} / \mathrm{g}$ \\
\hline
\end{tabular}

Table 2. Chemical composition of the treated fibres with respect to cellulose, hemicellulose and lignin

\begin{tabular}{llll}
\hline & Cellulose & Lignin & Hemicellulose \\
\hline Untreated & $43,90 \pm 0,53^{\mathrm{a}}$ & $17,96 \pm 0,5^{\mathrm{a}}$ & $27,67 \pm 0,35^{\mathrm{a}}$ \\
\hline Retting 1 week & $57,17 \pm 0,42^{\mathrm{b}}$ & $13,43 \pm 0,28^{\mathrm{b}}$ & $25,2 \pm 0,14^{\mathrm{b}}$ \\
\hline Retting 3 months & $59,84 \pm 0,84^{\mathrm{c}}$ & $12,66 \pm 0,42^{\mathrm{c}}$ & $24,3 \pm 0,42^{\mathrm{c}}$ \\
\hline Alcalin oven & $77,02 \pm 0,42^{\mathrm{d}}$ & $12,23 \pm 0,21^{\mathrm{c}}$ & $8,7 \pm 0,3^{\mathrm{d}}$ \\
\hline Alcalin autoclave & $86,1 \pm 0,13^{\mathrm{e}}$ & $9,12 \pm 0,16^{\mathrm{d}}$ & $3,5 \pm 0,28^{\mathrm{e}}$ \\
\hline Laccase & $85,92 \pm 0,46^{\mathrm{e}}$ & $6,57 \pm 0,88^{\mathrm{e}}$ & $6,3 \pm 0,42^{\mathrm{f}}$ \\
\hline Pectinase & $84,01 \pm 0,31^{\mathrm{f}}$ & $7,31 \pm 0,03^{\mathrm{f}}$ & $8,5 \pm 0,28^{\mathrm{d}}$ \\
\hline Xylanase & $83,45 \pm 0,12^{\mathrm{g}}$ & $6,03 \pm 0,08^{\mathrm{e}}$ & $10,31 \pm 0,02^{\mathrm{g}}$ \\
\hline
\end{tabular}

Means that do not share a letter are significantly different at a confidence level of $0.05(n=3)$ when compared to the control: for retting treatment the control was untreated fibres, for alkaline treatment the control was retting 1 week and for enzymatic treatment the control was alkaline autoclave. Tukey-Kramer statistical analysis was used to analyze all samples.

Table 3. Mechanical properties of alfa fibres for each defibration step

\begin{tabular}{lcccc}
\hline \multicolumn{1}{c}{ Treatment } & $\begin{array}{c}\text { Average diameter } \\
(\boldsymbol{\mu m})\end{array}$ & $\begin{array}{c}\text { Young's modulus } \\
(\mathbf{G P a})\end{array}$ & $\begin{array}{c}\text { Tensile strength } \\
\text { at break (MPa) }\end{array}$ & $\begin{array}{c}\text { Strain at } \\
\text { break }(\%)\end{array}$ \\
\hline Untreated fibres & $157.4 \pm 68.3^{\mathrm{a}}$ & $5 \pm 3.2^{\mathrm{a}}$ & $78 \pm 46^{\mathrm{a}}$ & $1.5 \pm 0.23^{\mathrm{a}}$ \\
\hline Retting 1 week & $29.9 \pm 11.9^{\mathrm{b}}$ & $21 \pm 12.9^{\mathrm{b}}$ & $419 \pm 251^{\mathrm{b}}$ & $1.95 \pm 0.54^{\mathrm{b}}$ \\
\hline Retting 3 months & $22.2 \pm 6.6^{\mathrm{c}}$ & $31 \pm 11.9^{\mathrm{c}}$ & $679 \pm 212^{\mathrm{c}}$ & $2.50 \pm 0.71^{\mathrm{c}}$ \\
\hline Alkaline oven & $25.9 \pm 10.1^{\mathrm{b}}$ & $37 \pm 16.4^{\mathrm{d}}$ & $923 \pm 332^{\mathrm{d}}$ & $2.65 \pm 0.72^{\mathrm{c}}$ \\
\hline Alkaline autoclave & $22.2 \pm 7.7^{\mathrm{d}}$ & $47 \pm 13^{\mathrm{e}}$ & $1023 \pm 268^{\mathrm{e}}$ & $2.35 \pm 0.52^{\mathrm{c}}$ \\
\hline Laccase & $21.2 \pm 6^{\mathrm{d}}$ & $43 \pm 13^{\mathrm{e}}$ & $1020 \pm 327^{\mathrm{e}}$ & $2.45 \pm 0.76^{\mathrm{c}}$ \\
\hline Pectinase & $24.3 \pm 8.6^{\mathrm{d}}$ & $58 \pm 17.4^{\mathrm{e}}$ & $1327 \pm 342^{\mathrm{e}}$ & $2.45 \pm 0.64^{\mathrm{c}}$ \\
\hline Xylanase & $22.6 \pm 6.2^{\mathrm{d}}$ & $66 \pm 23^{\mathrm{e}}$ & $1086 \pm 374^{\mathrm{e}}$ & $1.80 \pm 0.64^{\mathrm{e}}$ \\
\hline $\begin{array}{l}\text { The different letters are statistically different at a confidence level of } 0.05(\mathrm{n}=20) \text { when compared to the } \\
\text { control: for retting treatment the control was untreated fibres, for alkaline treatment the control was retting 1 } \\
\text { week and for enzymatic treatment the control was alkaline autoclave. Mann-Whitney Non-Parametric } \\
\text { statistical analysis was used to analyze all samples. This test was used given the small sample size and the non- } \\
\text { parametric pattern of the data. }\end{array}$
\end{tabular}


Table 4. Mechanical properties of alfa fibres according to the literature

\begin{tabular}{ccccccc}
\hline Source & $\begin{array}{c}\text { Average } \\
\text { diameter } \\
(\boldsymbol{\mu m})\end{array}$ & $\begin{array}{c}\text { Young's } \\
\text { modulus (GPa) }\end{array}$ & $\begin{array}{c}\text { Tensile } \\
\text { strength at } \\
\text { break (MPa) }\end{array}$ & $\begin{array}{c}\text { Elongation } \\
\text { at break } \\
(\boldsymbol{\%})\end{array}$ & $\begin{array}{c}\text { Extraction } \\
\text { process }\end{array}$ & $\begin{array}{c}\text { Specific } \\
\text { application }\end{array}$ \\
\hline Dallel (2012) & - & $8 \pm 2.7$ & $75 \pm 24.09$ & $2.8 \pm 2$ & $\begin{array}{c}\text { Mechanical } \\
\text { Chemical } \\
\text { Enzymatic }\end{array}$ & Textile \\
\hline $\begin{array}{c}\text { Ben Brahim } \\
\text { et al. (2007) }\end{array}$ & - & 21.5 & 247 & 1.96 & $\begin{array}{c}\text { Chemical } \\
\text { (paper } \\
\text { marker) }\end{array}$ & Composite \\
\hline $\begin{array}{c}\text { Bessadok et } \\
\text { al. (2009) }\end{array}$ & 70 & $71 \pm 23$ & $1480 \pm 800$ & $2.8 \pm 2$ & $\begin{array}{c}\text { Retting } \\
\text { Chemical }\end{array}$ & Composite \\
\hline & & & & & $\begin{array}{c}\text { Retting } \\
\text { Mechanical }\end{array}$ & Composite \\
This work & $24.34 \pm 8.6$ & $58 \pm 17$ & $1327 \pm 342$ & $2.4 \pm 0.6$ & $\begin{array}{c}\text { Chemical } \\
\text { Enzymatic }\end{array}$ \\
\hline
\end{tabular}

Table 5.Comparison of mechanical properties of different natural fibres

\begin{tabular}{|c|c|c|c|c|}
\hline Fibre & $\begin{array}{c}\text { Fibre } \\
\text { diameter }(\mu \mathrm{m})\end{array}$ & $\begin{array}{l}\text { Young's modulus } \\
\text { (GPa) }\end{array}$ & $\begin{array}{l}\text { Tensile strength } \\
\text { at break (MPa) }\end{array}$ & $\begin{array}{c}\text { Elongation } \\
\text { at break }(\%)\end{array}$ \\
\hline Alfa (this work) & $24.34 \pm 8.6$ & $58 \pm 17$ & $1327 \pm 342$ & $2.4 \pm 0.6$ \\
\hline Sisal $^{\mathrm{a}}$ & $240 \pm 27$ & $7.47 \pm 1.37$ & $462 \pm 71$ & $7.83 \pm 1.25$ \\
\hline Hemp $^{b}$ & $12 \pm 2.2$ & $35.5 \pm 17.3$ & $889 \pm 472$ & $2.6 \pm 2.2$ \\
\hline Kenaf $^{c}$ & $67.6 \pm 13.7$ & 40.74 & $785.37 \pm 128$ & $1.93 \pm 0.03$ \\
\hline Bambo $^{d}$ & $152 \pm 29.5$ & $46 \pm 1.2$ & $860 \pm 119$ & $1.9 \pm 0.3$ \\
\hline Flax $^{\mathrm{e}}$ & $15.6 \pm 3.1$ & $55.3 \pm 713.8$ & $1109 \pm 7333$ & $2.2 \pm 70.7$ \\
\hline E-glass ${ }^{\mathrm{e}}$ & $16.6 \pm 71.6$ & $77.8 \pm 74.8$ & $2319 \pm 7372$ & $3.0 \pm 70.9$ \\
\hline $\begin{array}{l}\text { a }{ }^{\mathrm{a}} \text { From Belaadi et a } \\
{ }^{\mathrm{b}} \text { From Marrot et a } \\
{ }^{\mathrm{c}} \text { From Mahjoub et } \\
{ }^{\mathrm{d}} \text { From Osorio et a } \\
{ }^{\mathrm{e}} \text { From Lefeuvre et }\end{array}$ & $\begin{array}{l}.(2013) \\
(2013) \\
\text { al. (2014) } \\
(2014) \\
\text { al. (2014) }\end{array}$ & & & \\
\hline
\end{tabular}

